\title{
Deep-Water Circulation over the Last Two Glacial Cycles Reconstructed from Authigenic Neodymium Isotopes in the Equatorial Indian Ocean (Core HI1808-GPC04)
}

\author{
Sunhwa Bang ${ }^{1}$ - Youngsook Huh ${ }^{1}$ (D) Boo-Keun $\mathrm{Khim}^{2} \cdot$ Hiroyuki Takata $^{3} \cdot$ Minoru Ikehara $^{4} \cdot \mathrm{Kiseong} \mathrm{Hyeong}^{5} \cdot$ \\ Inah $\mathrm{Seo}^{6} \cdot \mathrm{HyenGoo} \mathrm{Cho}^{7}$
}

Received: 1 August 2021 / Revised: 16 October 2021 / Accepted: 20 October 2021 / Published online: 15 November 2021

(c) The Author(s) 2021

\begin{abstract}
We reconstructed the past deep-water character of the equatorial Indian Ocean using the isotope ratio of neodymium $\left(\varepsilon_{\mathrm{Nd}}\right)$ in the Fe-Mn coating of mixed-species foraminifera. When compared with previous $\varepsilon_{\mathrm{Nd}}$ records at the same site (ODP 758) and at another site to the west (SK 129), the three datasets were consistent and showed glacial-interglacial variations, even though the other two records were extracted from different media (cleaned foraminifera and bulk sediment leach). This confirms that while the foraminiferal coating is the preferred medium for reconstructing past bottom water $\varepsilon_{\mathrm{Nd}}$ records, for carbonatedominated lithologies, weak acid extraction of bulk sediment is also a viable option offering high-resolution capabilities. When the lithology includes volcanic particles or high organics, the extraction protocol may need to be adjusted to guard against detrital contamination or a slight correction may need to be applied. During glacials, the deep waters bathing the equatorial Indian Ocean had a larger AABW component and during interglacials a larger NADW component. Our HI1808GPC04 record supplements the ODP 758 record in the interval with prominent AABW signal (MIS 6/5 transition and MIS 7) and reveals regional effects in some non-radiogenic intervals. The smaller differences between the HI1808-GPC04/ODP 758 and SK 129 records seem to reflect regional Nd input from river systems and non-radiogenic Nd from the boundaries.
\end{abstract}

Keywords Authigenic carbonate $\cdot$ Deep-water circulation $\cdot$ Foraminifera $\cdot$ Indian Ocean paleoceanography $\cdot$ Nd isotopes

Youngsook Huh

yhuh@snu.ac.kr

1 School of Earth and Environmental Sciences, College of Natural Sciences, Seoul National University, Seoul 08826 , Republic of Korea

2 Department of Oceanography, College of Natural Sciences, Pusan National University, Busan 46241, Republic of Korea

3 BK21 School of Earth and Environmental Systems, Pusan National University, Busan 46241, Republic of Korea

4 Center for Advanced Marine Research, Kochi University, Kochi 783-8502, Japan

5 Global Ocean Research Center, Korea Institute of Ocean Science and Technology, Busan 49111, Republic of Korea

6 Department of Earth and Environmental Sciences, College of Natural Science, Jeonbuk National University, Jeonju 54896, Republic of Korea

7 Department of Geology and Research Institute of Natural Science, College of Natural Science, Gyeongsang National University, Jinju 52828, Republic of Korea

\section{Introduction}

The neodymium isotopic composition $\left(\varepsilon_{\mathrm{Nd}}=\left[\left({ }^{143} \mathrm{Nd} /{ }^{144} \mathrm{Nd}\right)_{\mathrm{sample}} /\left({ }^{143} \mathrm{Nd} /{ }^{144} \mathrm{Nd}\right)_{\mathrm{CHUR}}-1\right] \times 10^{4}\right.$; $\left({ }^{143} \mathrm{Nd} /{ }^{144} \mathrm{Nd}\right)_{\mathrm{CHUR}}=0.512638$; Jacobsen and Wasserburg 1980) of seawater is considered a quasi-conservative circulation tracer, because water masses with locally specific $\varepsilon_{\mathrm{Nd}}$ maintain that value as they participate in the global thermohaline circulation (Goldstein and Hemming 2003). The short residence time of $\mathrm{Nd}$ ensures that the $\varepsilon_{\mathrm{Nd}}$ value of seawater reflects the age and rock type of surrounding continents, and globally the $\varepsilon_{\mathrm{Nd}}$ varies from relatively non-radiogenic North Atlantic (-12.3 to - 12.6; Piepgras and Wasserburg 1987; Jeandel 1993) to radiogenic North Pacific ( -3.3 to -3.8;Piepgras and Jacobsen 1988; Tachikawa et al. 2017).

Records of past variations in seawater $\varepsilon_{\mathrm{Nd}}$ have been retrieved using different media. The two most frequently used for high temporal resolution reconstructions are the authigenic $\mathrm{Fe}-\mathrm{Mn}$ oxyhydroxides of bulk sediments and the Fe-Mn coating on foraminifera. In the North and South 
Atlantic, for example, the two media give consistent results within experimental uncertainty (Piotrowski et al. 2012). In the case of the Northeast Pacific, bulk sediment leaching can suffer from contamination by diagenetic Nd (Abbott et al. 2015; Du et al. 2016). The critical consideration seems to be the lithology, e.g. the presence of radiogenic and labile volcanic ash and organics leading to reductive dissolution of the Fe-Mn phase after deposition. The lithology of the South Atlantic core is dominated by calcareous nannofossil ooze (Pufahl et al. 1998), but the Northeast Pacific core (Du et al. 2016) is mainly lithogenic (>90\%) and carbonate-poor $(<5 \%)$. Therefore, while the bulk sediment leach offers a great advantage in terms of temporal resolution, it is important to adjust the sequential leaching protocol to match the specific lithology of the core and to confirm the results using different media.

The constrasting $\varepsilon_{\mathrm{Nd}}$ between the Atlantic and the Pacific is important in interpreting the deep-water circulation of the Indian Ocean, as a mixture of the North Atlantic Deep Water (NADW) and Antarctic Bottom Water (AABW) flows into the Indian Ocean (Fig. 1; Robinson and van de Flierdt 2009; Roberts et al. 2010; Piotrowski et al. 2012). NADW forms in two broad regions of the North Atlantic (Hillaire-Marcel et al. 2001)—during the deglacial, in the relatively less radiogenic Labrador Sea $\left(\varepsilon_{\mathrm{Nd}}-18\right.$ to -24 ; Piotrowski et al. 2012) and during the glacial, in the relatively more radiogenic Nordic Seas $\left(\varepsilon_{\mathrm{Nd}}\right.$ -8 to -13 ; Lacan and Jeandel 2004; Piotrowski et al. 2012). AABW forms along the Antarctic shelf, in the Weddell Sea $\left(\varepsilon_{\mathrm{Nd}}-7.9\right.$ to -10.9 ; Stichel et al. 2012) and the Ross Sea $\left(\varepsilon_{\mathrm{Nd}} \sim-7\right.$; Basak et al. 2015, 2018). During glaciation, AABW formation in the Ross Sea remained active (Basak et al. 2018), while the deep water in the Weddell Sea was isolated (Huang et al. 2020). Thus, AABW was also more radiogenic $\left(\varepsilon_{\mathrm{Nd}}-6.0\right.$ to -6.8$)$ in the glacial than in the deglacial $\left(\varepsilon_{\mathrm{Nd}}-7\right.$ to -9$)$ (Piepgras and Wasserburg 1982; Howe et al. 2016; Hu et al. 2016). Since the $\varepsilon_{\mathrm{Nd}}$ ranges of NADW and AABW are very different and the direction of change with climate is similar, the radiogenic shift in $\varepsilon_{\mathrm{Nd}}$ in the deep water of the Indian Ocean can be interpreted as strengthening of AABW and the non-radiogenic shift as strengthening of NADW (Piotrowski et al. 2009; Gourlan et al. 2010; Roberts et al. 2010; Wilson et al. 2015).

In this study, we revisit ODP site 758 (Fig. 1) where pioneering studies have reconstructed past seawater $\varepsilon_{\mathrm{Nd}}$ using (i) cleaned foraminifera (Burton and Vance 2000) and (ii) bulk sediment leach (Gourlan et al. 2010; Table 1). Burton and Vance (2000) utilized the oxidative-reductive cleaning technique to obtain what they took to be $\mathrm{CaCO}_{3}$ lattice-bound $\mathrm{Nd}$ and interpreted the record as the $\varepsilon_{\mathrm{Nd}}$ of the surface water in which the planktonic foraminifera grew. Gourlan et al. (2010) applied a weak acetic acid leach to extract the authigenic fraction containing carbonate, $\mathrm{MnO}_{2}$, and intracellular organic matter and interpreted their record as reflecting the composition of the upper $1000 \mathrm{~m}$ of the water column where the $\mathrm{MnO}_{2}$ precipitate formed. More recently, it has been found that the foraminifera continue reequilibrating as they fall through the water column and that the $\mathrm{MnO}_{2}$ coating is acquired in the bottom waters (Roberts et al. 2012). Nowadays, the $\varepsilon_{\mathrm{Nd}}$ of uncleaned foraminifera, i.e. the authigenic $\mathrm{Fe}-\mathrm{Mn}$ coating on the foraminifera, is more widely used and is interpreted as representing the bottom water composition (Roberts et al. 2012; Tachikawa et al. 2014). Moreover, Yu et al. (2018) have documented that the $\varepsilon_{\mathrm{Nd}}$ values of the cleaned planktonic foraminifera in the Bay of Bengal area are consistent with the bottom water and not surface water values.
Fig. 1 Core location and deepwater circulation in the Indian Ocean (Robinson and van de Flierdt 2009; Roberts et al. 2010; Piotrowski et al. 2012). The yellow star marks the location of HI1808-GPC04 (2991 m depth; this study), and circles mark those of cores mentioned in the text. The black arrows indicate the general deep-water circulation in the Indian Ocean. The major ridges are indicated by yellow dashed lines: the Ninetyeast Ridge (N) and the Chagos-Laccadive Ridge ()). The Andaman sea (A) and mouths of the Ganges-Brahmaputra (@) and the IrrawaddySalween (I) river systems are also shown

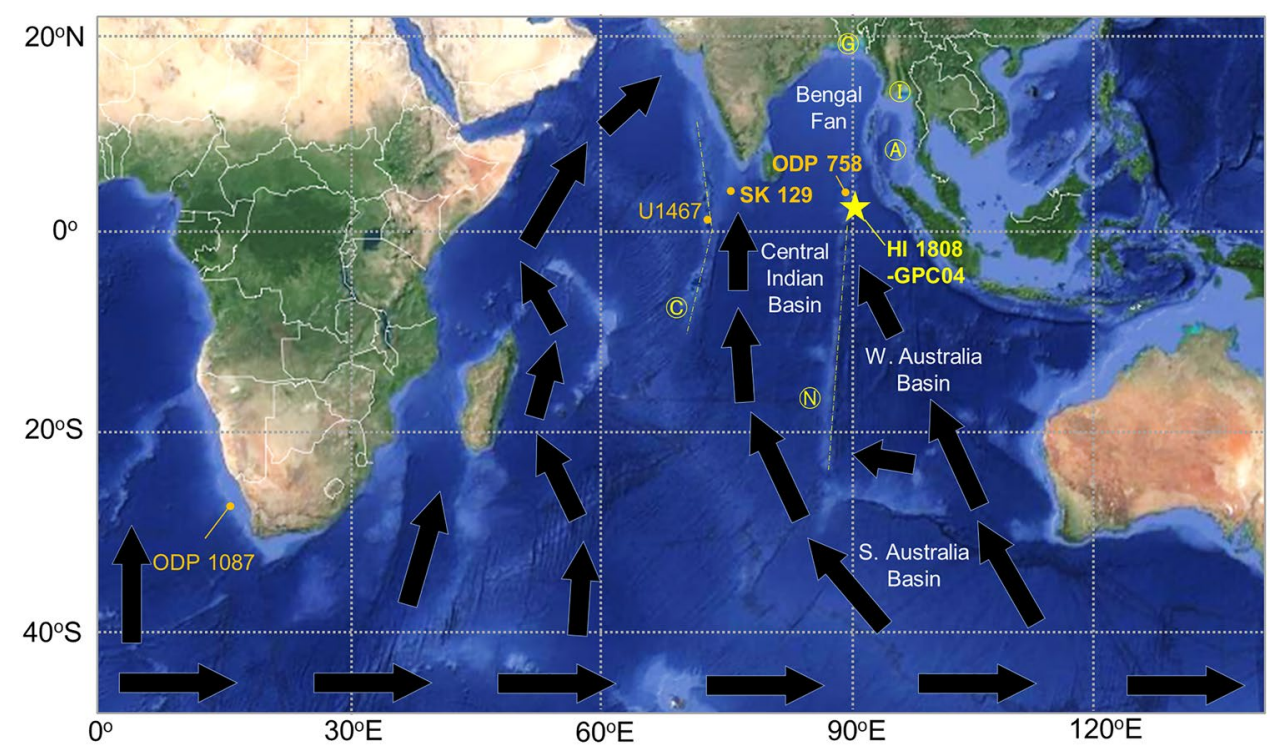


Table 1 Comparison of materials and pretreatment methods for authigenic $\varepsilon_{\mathrm{Nd}}$

\begin{tabular}{|c|c|c|c|c|}
\hline & This study & Burton and Vance (2000) & Gourlan et al. (2010) & Wilson et al. (2015) \\
\hline Material & Foraminifera (mixed species) & Foraminifera (single species) & Bulk sediment & Bulk sediment \\
\hline Dissolution & $1 \mathrm{M}$ acetic acid & $\begin{array}{l}\text { Oxidative-reductive cleaning } \\
0.05 \mathrm{M} \text { nitric acid }\end{array}$ & $1 \mathrm{M}$ acetic acid & $\begin{array}{l}0.44 \mathrm{M} \text { acetic acid } \\
\text { (decarbonation) } \\
0.02 \mathrm{M} \mathrm{HH} \text { in } 4.4 \mathrm{M} \\
\text { acetic acid }\end{array}$ \\
\hline Source of Nd & Fe-Mn oxide coating & Foraminiferal shell & $\begin{array}{l}\mathrm{MnO}_{2} \text { coating, carbonate, } \\
\text { organics }\end{array}$ & Fe-Mn oxide coating \\
\hline
\end{tabular}

$H H$ hydroxylamine-hydrochloride

There is also another record in the equatorial Indian Ocean, SK 129 (Fig. 1) whose $\varepsilon_{\mathrm{Nd}}$ was originally reconstructed for the last glacial cycle by leaching of bulk sediments (Piotrowski et al. 2009). It was then extended to the penultimate glacial cycle, and after a slight correction the sediment leach record agreed with additional $\varepsilon_{\mathrm{Nd}}$ measurements of foraminifera and fish teeth (Wilson et al. 2015; Table 1).

We have analyzed the $\varepsilon_{\mathrm{Nd}}$ of the Fe-Mn coating on planktonic foraminifera using a core very close to ODP 758 , and we compared the result with the previous records in the Indian Ocean-ODP 758 and SK 129. It is a rare opportunity to have $\varepsilon_{\mathrm{Nd}}$ reconstructions obtained from three independent recording media for the same or nearby sites, which allows us to examine whether the different media reveal a consistent picture of the deep-water circulation in the equatorial Indian Ocean over the last two glacial cycles and whether the differences offer new insights or venues of further research.

\section{Materials and Methods}

\subsection{Regional Setting}

Core HI1808-GPC04 (5²4' 01" N, 90 21' 46" E, $2991 \mathrm{~m}$ water depth; Fig. 1) was retrieved during the 2018 Indian Ocean expedition of R/V Isabu of the Korea Institute of Ocean Science and Technology (KIOST). The core was collected from the northern end of the Ninetyeast ridge and is close to the ODP site $758\left(5^{\circ} 23^{\prime} \mathrm{N}, 90^{\circ} 21^{\prime} \mathrm{E}, 2925 \mathrm{~m}\right.$ water depth). The location is $\sim 1800 \mathrm{~km}$ directly south of the Ganges-Brahmaputra delta, which is one of the biggest sediment supply systems and is fed by weathering of the Himalayas (Wasson 2003; Rahman et al. 2018; Fig. 1). According to the sediment composition, clay minerals, and $\mathrm{Nd}$ and $\mathrm{Sr}$ isotope data of the Bay of Bengal and ODP 758, the detrital sediments reaching ODP 758 are predominantly from the Ganges-Brahmaputra river system with a significant input from the Irrawaddy-Salween river system (Colin et al. 1999; Joussain et al. 2016; Ali et al. 2021; Song et al. 2021). The latter may increase (1) in the summer monsoon season when the Andaman Sea is flooded (Zahirovic et al. 2016; Ali et al. 2021) and (2) in the inter-monsoon season when the southward flow from the Andaman Sea to the Ninetyeast Ridge at intermediate to deep depths increases (Liao et al. 2020).

Core SK $129\left(3^{\circ} \mathrm{N}, 76^{\circ} \mathrm{E}, 3800 \mathrm{~m}\right.$ water depth) is located on the eastern side of the Chagos-Laccadive Ridge and $\sim 550 \mathrm{~km}$ from the southern tip of India (Fig. 1). All three sites are influenced by the Circumpolar Deep Water $(\mathrm{CDW})$ from the Southern Ocean, which reaches the sites via the West Australia Basin (ODP 758) or the South Australia and Central Indian basins (SK 129; Mantyla and Reid 1995; Fig. 1).

A characteristic feature of this area is the seasonal change in the direction of the surface ocean current. In winter, the northeast monsoon drift travels from Singapore to the African continent along the Indian Ocean coastline, and in summer the southwest monsoon drift appears in the opposite direction (Achyuthan et al. 2014).

\subsection{Core Information and Sampling}

The age model and marine isotope stage (MIS) assignment of core HI1808-GPC04 is based on tie point correlation with the global LR04 stack (Lisiecki and Raymo 2005; Fig. 2). $\delta^{18} \mathrm{O}$ data were obtained from planktonic foraminifera $\mathrm{Glo}$ bigerinoides sacculifer using IsoPrime at the Center for Advanced Marine Core Research of Kochi University, Japan. In addition, radiocarbon ages (Table 2) were determined on mixed-species planktonic foraminifera by accelerator mass spectrometry at the Beta Analytic Radiocarbon Dating Laboratory. The uncertainty of the ${ }^{14} \mathrm{C}$ age is $<150$ years. The ${ }^{14} \mathrm{C}$ age was calibrated using the high probability density range method (BetaCal 3.21 ver.) based on MARINE20 data (Stuiver and Reimer 1993; Heaton et al. 2020; Stuiver et al. 2021). Calib v.8.1 software (http://calib.org) was used to convert the ${ }^{14} \mathrm{C}$ age to calendar years BP, with the local reservoir age $(17 \pm 70 \mathrm{yr})$ of Nicobar Island $\left(9^{\circ} \mathrm{N}, 94^{\circ} \mathrm{E}\right.$; Southon et al. 2002) applied. The age model for cores ODP 758 and SK 129 are also tuned to the LR04 stack (Gourlan et al. 2010; Piotrowski et al. 2009; Wilson et al. 2015). 


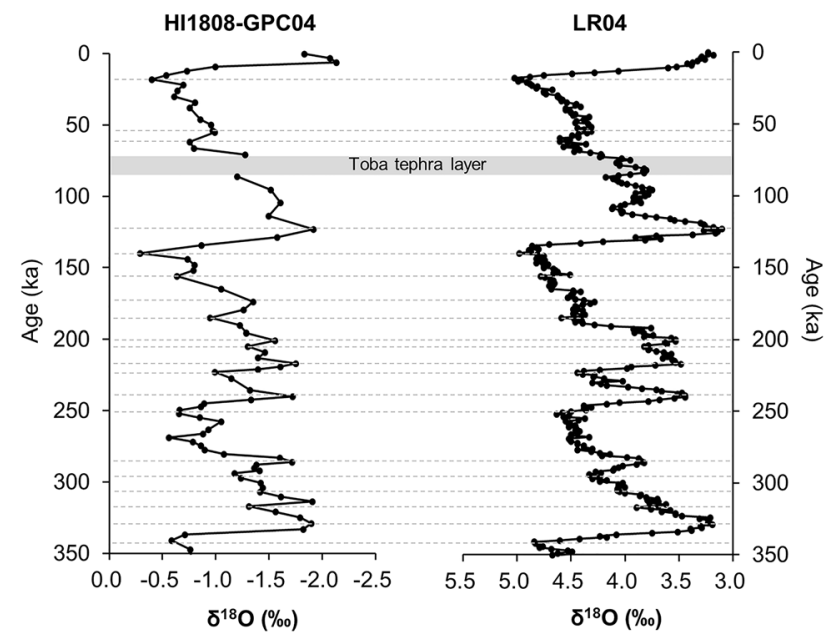

Fig. 2 Age model of core HI1808-GPC04. The dotted lines connect $\delta^{18} \mathrm{O}$ tie points between the HI1808-GPC04 and the LR04 stack (Lisiecki and Raymo 2005). The gray shaded band represents the Toba tephra layer ( $75 \mathrm{ka}$; Farrell and Janacek 1991)

Table 2 The $\varepsilon_{\mathrm{Nd}}$ and $\delta^{18} \mathrm{O}$ data of core HI1808-GPC04

\begin{tabular}{lcllll}
\hline $\begin{array}{l}\text { Depth } \\
(\mathrm{cm})\end{array}$ & $\begin{array}{l}\text { Calendar age } \\
(\text { kyr BP })\end{array}$ & $\varepsilon_{\mathrm{Nd}}$ & $\begin{array}{l}\varepsilon_{\mathrm{Nd}} \\
( \pm 2 \sigma)\end{array}$ & $\begin{array}{l}\delta^{18} \mathrm{O} \\
(\% \circ)\end{array}$ & $\begin{array}{l}\mathrm{CaCO}_{3} \\
(\%)\end{array}$ \\
\hline 0 & 0 & -9.70 & 0.26 & -1.84 & 59.5 \\
10 & $9 *$ & - & - & -2.13 & 55.2 \\
15 & 13 & -8.25 & 0.29 & -1.00 & 60.5 \\
30 & $25^{*}$ & -7.42 & 0.36 & -0.40 & 54.1 \\
45 & $35^{*}$ & -7.86 & 0.10 & -0.61 & 58.1 \\
60 & 44 & -8.55 & 0.23 & - & 58.0 \\
125 & 95 & -9.49 & 0.28 & -1.52 & 67.9 \\
140 & 123 & -9.51 & 0.14 & -1.92 & 55.3 \\
155 & 140 & -7.94 & 0.37 & -0.29 & 58.7 \\
170 & 152 & -7.59 & 0.31 & -0.79 & 57.8 \\
185 & 174 & -8.52 & 0.25 & -1.35 & 57.7 \\
200 & 190 & -9.45 & 0.22 & -1.23 & 62.6 \\
230 & 217 & -8.83 & 0.24 & -1.75 & 64.3 \\
240 & 221 & -8.94 & 0.34 & -1.40 & 55.7 \\
245 & 223 & -8.96 & 0.19 & -0.99 & 58.4 \\
260 & 236 & -9.46 & 0.15 & -1.32 & 68.2 \\
275 & 245 & -9.48 & 0.11 & -0.89 & 61.8 \\
290 & 252 & -8.95 & 0.24 & -0.65 & 52.9 \\
305 & 260 & -8.29 & 0.20 & -1.05 & 63.2 \\
365 & 292 & -9.48 & 0.31 & -1.41 & 71.1 \\
425 & 333 & -10.38 & 0.25 & -1.82 & 58.2 \\
\hline
\end{tabular}

*Radiocarbon age measurements (uncertainty $<150$ year)
The lithology of core HI1808-GPC04 is dominated by carbonate ooze, with a tephra layer at $75 \mathrm{ka}$. The $\mathrm{CaCO}_{3}$ content $(53-71 \%)$ and $\delta^{18} \mathrm{O}$ age tie points with LR04 (Lisiecki and Raymo 2005) are in good agreement with ODP 758.

At least $30 \mathrm{mg}$ of mixed planktonic foraminifera species were picked from the $125-300 \mu \mathrm{m}$ size range. These samples were carefully crushed between glass slides, checked under the microscope to discard detrital particles, and ultrasonicated with Milli-Q water. After drying, the samples were checked again for detrital residue under the microscope, and if such particles remained they were put through another ultrasonication cycle. After washing, the samples were dissolved in $1 \mathrm{M}$ acetic acid following the recommended procedure of Tachikawa et al. (2014). This method differs from previous studies (Burton and Vance 2000; Gourlan et al. $2010)$ in that it retrieves the authigenic Fe-Mn oxide coating acquired from the bottom water, with the foraminifera acting as a low-Nd carrier and ensuring that detrital $\mathrm{Nd}$ is not incorporated (Table 1).

The supernatants from centrifugation was moved to Teflon vials and dried on a hotplate at $60{ }^{\circ} \mathrm{C}$. The residue was completely dissolved in $1 \mathrm{M} \mathrm{HNO}_{3}$ and $\mathrm{Nd}$ separated following McCoy-West et al. (2017). This two-column method has an advantage for samples with $\mathrm{CaCO}_{3}$ matrix, because cation exchange resin (AG50W-X8, 200-400 mesh) is used before the lanthanide-element specific resin (Ln-B25-50, Eichrom, 50-100 $\mu \mathrm{m}$ ). After column separation, samples were dried down and re-dissolved in $2 \% \mathrm{HNO}_{3}$ for $\mathrm{MC}$ ICPMS analysis.

The $\mathrm{Nd}$ isotope ratio was measured using NuPlasma 3 MC-ICPMS with Aridus-II desolvating nebulizer at the Seoul National University Institute of Basic Science and Technology. All Nd isotope data were normalized by applying a mass bias correction to ${ }^{146} \mathrm{Nd} /{ }^{144} \mathrm{Nd}=0.7219$. Standards JNdi- $1\left({ }^{143} \mathrm{Nd} /{ }^{144} \mathrm{Nd}=0.512115 \pm 0.000001, n=275\right)$ and CGND1- $1\left({ }^{143} \mathrm{Nd} /{ }^{144} \mathrm{Nd}=0.512200 \pm 0.0000003\right.$, $n=330)$ at similar concentrations as the samples $(\sim 20 \mathrm{ppb})$ were repeatedly run in each analytical session. The reproducibility $(2 \sigma)$ for the standard solutions was $\sim 0.4 \varepsilon_{\mathrm{Nd}}$ unit, and the reproducibility of each sample was also within this range (Table 2). The blank was less than $0.1 \%$ of the standard and sample $(<20 \mathrm{ppt})$.

\section{Results and Discussion}

\subsection{The New $\varepsilon_{\text {Nd }}$ Record of HI1808-GPCO4 and Comparison with ODP 758 and SK 129}

Our new $\varepsilon_{\text {Nd }}$ record HI1808-GPC04 shows distinctive G-IG variations and ranges in value from -7.4 to -10.4 (Figs. 3 and 4). Although the two $\varepsilon_{\mathrm{Nd}}$ records of ODP 758 utilize different media, Mn-cleaned planktonic 


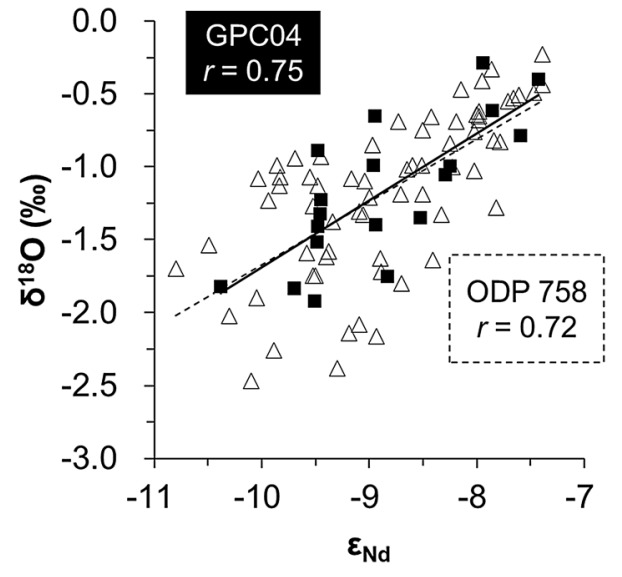

Fig. 3 Cross-plot of $\varepsilon_{\mathrm{Nd}}$ and planktonic $\delta^{18} \mathrm{O}$ from two datasets on the Ninetyeast Ridge. Core HI1808-GPC04 (filled squares; This study) and ODP 758 (open triangles; Burton and Vance 2000; Gourlan et al. 2010)

foraminifera (Burton and Vance 2000) and acetic acidleached bulk sediment (Gourlan et al. 2010), the two methods gave consistent results when applied to the same samples $(r=0.94, n=7, p<0.0005)$ (Gourlan et al. 2010). The Burton and Vance (2000) record focuses on the last G-IG cycle, whereas the Gourlan et al. (2010) record is longer, extending to $4 \mathrm{Ma}$. Overall, our HI1808-GPC04 is in good agreement with the two ODP 758 records (Figs. 3 and 4), even though we used yet another media-the $\mathrm{Fe}-\mathrm{Mn}$ coating on planktonic foraminifera. As HI1808-GPC04 and ODP 758 cores are geographically very close and other properties such as the $\delta^{18} \mathrm{O}$ of planktonic foraminifera are well-matched (Fig. 3), we infer that the two cores are sampling the same bottom water. That the two media are in such good agreement bears remark. The sequential extraction protocol of bulk sediments generally needs to be fine-tuned depending on local lithology, as labile volcanic material easily distorts the authigenic signal (Wilson et al. 2012; Du et al. 2016). In the case of the cores on the Ninetyeast Ridge dominated by carbonate lithology, a weak acetic acid leach seems to be an adequate extraction technique to recover the authigenic fraction. The only major volcanic episode is the Toba tephra layer at $\sim 75 \mathrm{ka}$ in MIS 4 (Farrell and Janacek 1991; Fig. 2), but that stratigraphic interval was not analyzed for $\varepsilon_{\mathrm{Nd}}$ in either of the cores.

The original $\varepsilon_{\mathrm{Nd}}$ record at SK 129 (Piotrowski et al. 2009) was slightly offset toward radiogenic values from the HI1808-GPC04 or the ODP 758 records, but the updated and corrected record (Wilson et al. 2015) is broadly similar in terms of both the absolute values and the G-IG variations (Fig. 4).

In making detailed comparisons among the three records, we address three issues. First, the three records are all tuned to the global LR04 stack, despite differences in the number of absolute age determinations. The maximum uncertainty in age for the period of our study is estimated to be $\sim 4 \mathrm{kyr}$. Second, the sampling resolution differs among the three records, with the higher-resolution SK 129 inevitably showing greater variability. Third, the ODP 758 (Gourlan et al. 2010) and SK 129 records were obtained by leaching bulk sediments using $1 \mathrm{M}$ and $0.44 \mathrm{M}$
Fig. 4 Indian Ocean $\varepsilon_{\mathrm{Nd}}$ records at the two different locations. a $\varepsilon_{\mathrm{Nd}}$ of HI1808-GPC04 (red square; This study) and ODP 758 (light green diamond; Burton and Vance 2000, green triangle; Gourlan et al. 2010) and $\mathbf{b} \varepsilon_{\mathrm{Nd}}$ of SK 129 (light navy circle; Wilson et al. 2015). Cores HI1808-GPC04 and ODP 758 are on the Ninetyeast Ridge, and core SK 129 is on the Chagos-Laccadive Ridge. Glacial stages are indicated with gray shading

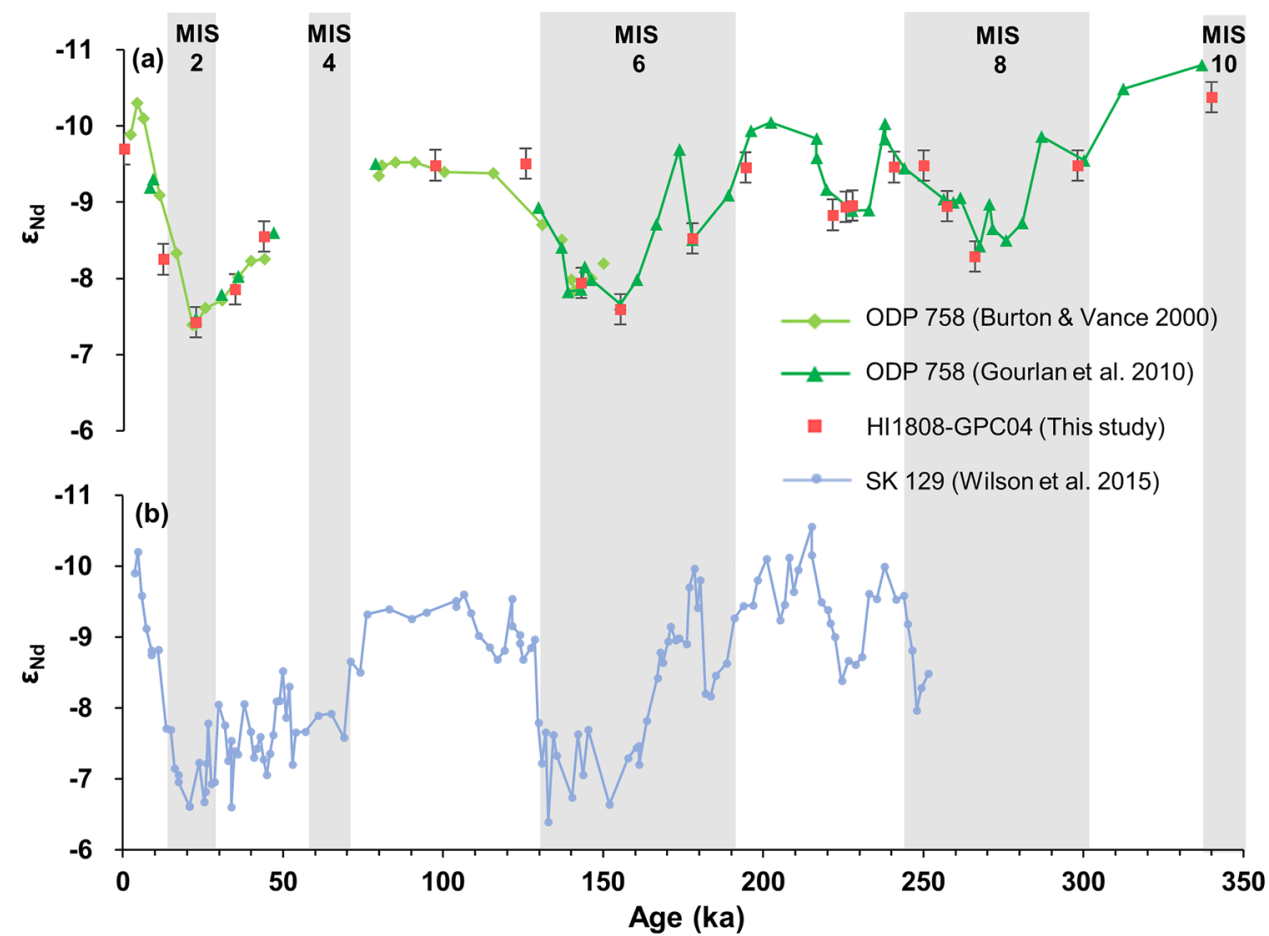


acetic acid, respectively (Table 1). This method is more amenable to contamination from unintended leaching of labile volcanic material, and such volcanic contamination should result in more radiogenic $\varepsilon_{\mathrm{Nd}}$ values.

The small departures between the two sites, one on the Ninetyeast Ridge and another on the Chagos-Laccadive Ridge, are interesting in that the two sites are both in the equatorial Indian Ocean, generally in the same pathway of the AABW. In MIS 7, SK 129 displays a non-radiogenic peak at $215 \mathrm{ka}\left(\varepsilon_{\mathrm{Nd}}=-10.56\right)$ compared to the HI1808-GPC04 (217 ka, $\left.\varepsilon_{\mathrm{Nd}}=-8.83\right)$ or ODP $758\left(215 \mathrm{ka}, \varepsilon_{\mathrm{Nd}}=-9.17\right)$ (Fig. 4). In MIS 6, the HI1808-GPC04 and ODP 758 are generally less radiogenic than SK 129 except for the nonradiogenic peak ( -9.97 to -9.80$)$ at $178-180 \mathrm{ka}$. The largest difference between the two sites occurs at the MIS $6 / 5$ boundary. ODP 758 becomes less radiogenic $(-8.41$ to -8.93 ) from 134 to $127 \mathrm{ka}$. SK 129 follows the same trend, but the range is larger (from -7.62 to -8.85 ) and there is a very radiogenic peak of -6.39 at $133 \mathrm{ka}$. In MIS 5, both sites display a relatively constant $\varepsilon_{\mathrm{Nd}}$ at -9.5 except for a radiogenic peak ( -9.02 to -8.68$)$ for SK 129 at $111-116 \mathrm{ka}$. This may be an effect of the higher sample resolution of SK 129. During MIS 3, HI1808-GPC04 and ODP 758 tend to rapidly become radiogenic. Although SK 129 shows a change in a similar direction, the higher sample resolution reveals several superimposed peaks. On average, the SK129 displays more radiogenic values than HI1808-GPC04 and ODP 758 and in MIS 2 reach more radiogenic values: -6.61 for SK 129 versus -7.39 for ODP 758 at $21 \mathrm{ka}$. This difference of $0.78 \varepsilon_{\mathrm{Nd}}$ units is greater than the $2 \sigma$ analytical uncertainty. The core-top values tend to merge to a similar non-radiogenic $\varepsilon_{\mathrm{Nd}}$ value of -10.3 .

Although variations on the G-IG time scale are consistent, the SK 129 record appears to be slightly more radiogenic than HI1808-GPC04/ODP 758 in MIS 2, 3, and 6/5 (Fig. 4). The radiogenic values for SK 129 cannot be easily explained by volcanic contamination, because a stronger acid leach (1 M versus $0.44 \mathrm{M}$ acetic acid; Table 1) was applied for ODP 758 (Gourlan et al. 2010). If unintended dissolution of volcanic material occurred during sample pretreatment, the ODP 758 record is more likely to have been affected. The less radiogenic values for the Ninetyeast Ridge cores can instead be attributed to differential input of sediments from the rivers and local exchange in the bottom water or pore waters. In addition to input from the Ganges-Brahmaputra, SK 129 (Chagos-Laccadive Ridge) receives detrital (non-radiogenic) input from peninsular rivers discharging into the western Bay of Bengal, which decreases drastically when the summer monsoon is weaker (Suresh and Bagati 1998) as occurs during glacial periods (Zhisheng et al. 2011). Detrital input from the Ganges-Brahmaputra river system has a significant abundance in the Ninetyeast Ridge (Ali et al. 2021; Song et al. 2021) and is a factor that can provide non-radiogenic $\varepsilon_{\mathrm{Nd}}(\sim-16.1$; Colin et al. 1999; Robinson et al. 2007). The Ninetyeast Ridge (HI1808-GPC04 and ODP 758) receives sediment input from the Irrawaddy-Salween river via the Andaman Sea, in addition to input from the Ganges-Brahmaputra river. This non-radiogenic riverine input would have decreased during glacial periods with weaker summer monsoon but not to the extent of the western Bay of Bengal coastline. In addition, the strengthened intermediate-to-deep water flow would have supplied non-radiogenic material from the Andaman Sea to the Ninetyeast Ridge (Liao et al. 2020). Indeed, the $\varepsilon_{\mathrm{Nd}}$ of Andaman Sea sediments ( -11.2 to -8.7 ; Lee et al. 2020 ), sourced from the Irrawaddy $(-7.3$ to -6.8 ; Giosan et al. 2018) and Salween ( -14.7 to -15.4 ; Damodararao et al. 2016), is similar to the non-radiogenic values found in the cores HI1808-GPC04 and ODP 758.

The non-radiogenic peaks of SK 129 in MIS 6 and 7 could be explained by local input from boundary exchange (Wilson et al. 2012). Boundary exchange is estimated to extend its influence to $\sim 1000 \mathrm{~km}$, and SK 129 is $\sim 550 \mathrm{~km}$ from the tip of the Indian peninsula and Sri Lanka. Why the input from the Bay of Bengal or boundary exchange should be more prominent at certain periods is not clear at present.

Wilson et al. (2015) pointed out the similarity, especially for MIS 5 and 7, of the SK $129 \varepsilon_{\mathrm{Nd}}$ record with the Chinese loess grain size record, a proxy of the strength of the winter monsoon (wind blowing from the northeast) in Asia (Yang and Ding 2014; Fig. 5g). They posited that there was close coupling between the atmosphere and the ocean to yield such similarity. During glacial periods the inflow of NADW to the Southern Ocean was reduced which resulted in more radiogenic $\varepsilon_{\mathrm{Nd}}$ in the Indian Ocean (Fig. 5c). At the same time, an active Northern Hemisphere atmospheric circulation increased the strength of the winter monsoon in Asia, increasing the loess grain size. However, such similarity to the Chinese loess record is not apparent for other cores upstream of the Indian Ocean, in the North Atlantic (Böhm et al. 2015; Fig. 5d) and the South Atlantic (Hu et al. 2016; Fig. 5e). It is also interesting that the maximum aeolian grain size record from a nearby site in the Maldives (IODP Exp. 359 site U1467; Lindhorst et al. 2019; Fig. 5f) does not bear many similarities to the Chinese loess grain size record.

\section{2 $\varepsilon_{\text {Nd }}$ Reflecting G-IG Water Circulation Changes}

We will call the records at the Ninetyeast Ridge the HI1808GPC04/ODP 758 record (Fig. 5c). The HI1808-GPC04/ODP 758 record shows a good correlation with the planktonic $\delta^{18} \mathrm{O}$ record ( $r=0.75, n=20, p<0.0005)$, as has been pointed out previously ( $r=0.72$; Gourlan et al 2010; Fig. 3 ). The time lag between the bottom water $\varepsilon_{\mathrm{Nd}}$ and the surface water $\delta^{18} \mathrm{O}$ is considered minimal for our time frame. Our $\delta^{18} \mathrm{O}$ record (Fig. 2), as well as that of ODP 758, reflect surface water 


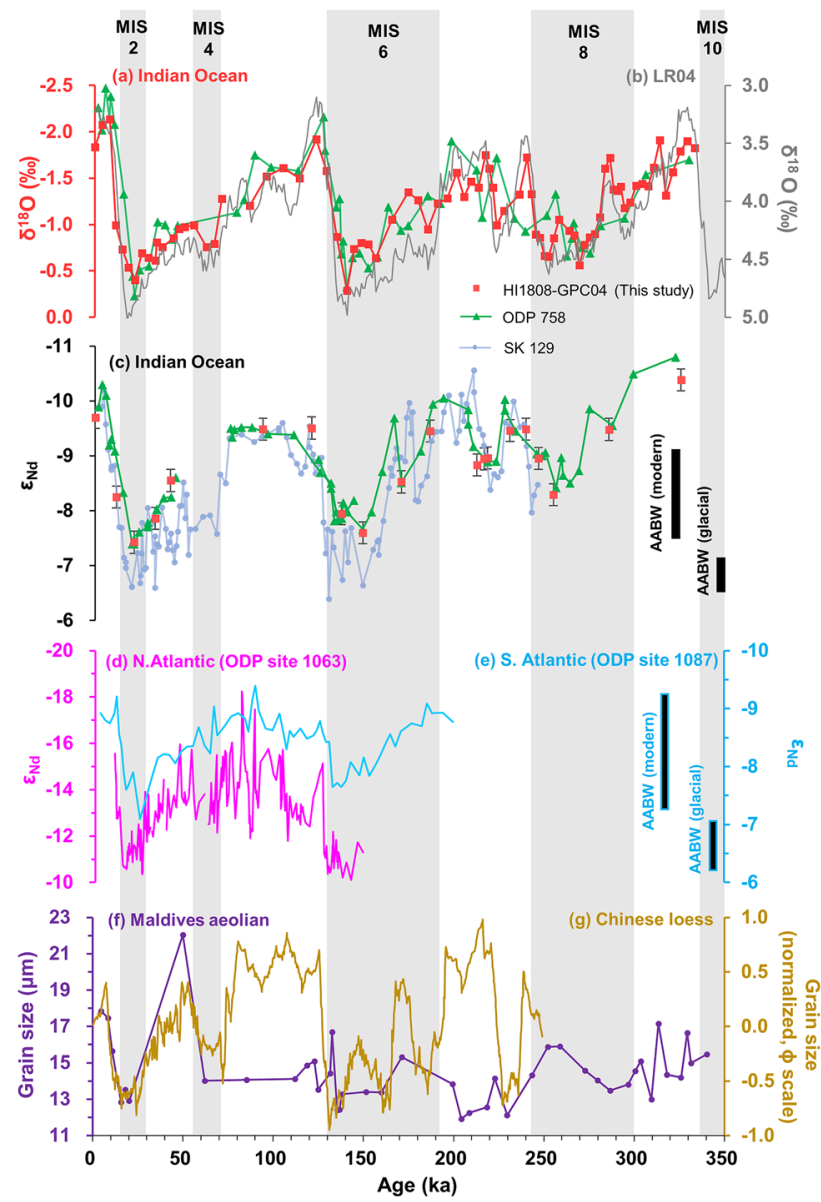

Fig. 5 Indian Ocean $\varepsilon_{\mathrm{Nd}}$ records with other regional proxies. a $\delta^{18} \mathrm{O}$ of HI1808-GPC04 (red square) and ODP 758 (green triangle; Chen et al. 1995), b the LR0 $4 \delta^{18} \mathrm{O}$ stack (gray line; Lisiecki and Raymo 2005), c composite $\varepsilon_{\mathrm{Nd}}$ of HI1808-GPC04 (red square; This study)/ ODP 758 (green triangle; Burton and Vance 2000; Gourlan et al. 2010) plotted with $\varepsilon_{\mathrm{Nd}}$ of SK 129 (light navy circle; Wilson et al. 2015), with the bars indicating the $\varepsilon_{\mathrm{Nd}}$ range of modern AABW (-7 to -9; Piepgras and Wasserburg 1982; Goswami et al. 2012; Yu et al. 2018) and glacial Antarctic Intermediate Water (AAIW) and AABW ( -6.0 to -6.8 ; Howe et al. 2016; Hu et al. 2016), $\mathbf{d} \varepsilon_{\mathrm{Nd}}$ record of the North Atlantic, ODP $1063\left(172,33^{\circ} 41^{\prime} \mathrm{N}, 57^{\circ} 37^{\prime} \mathrm{W}\right.$, water depth $4584 \mathrm{~m}$ ) (pink line; Böhm et al. 2015), e $\varepsilon_{\mathrm{Nd}}$ record of the South Atlantic ODP $1087\left(31^{\circ} 27.88^{\prime} \mathrm{S}, 15^{\circ} 18.65^{\prime} \mathrm{E}\right.$, water depth $\left.1372 \mathrm{~m}\right)$ (light blue line; $\mathrm{Hu}$ et al. 2016), $\mathbf{f}$ maximum aeolian grain size record of the Maldives core IODP Exp. 359 Site U1467 (4 ${ }^{\circ} 51.0274^{\prime} \mathrm{N}$, $73^{\circ} 17.0223^{\prime} \mathrm{E}$, water depth $487.4 \mathrm{~m}$ ) (purple line with point; Lindhorst et al. 2019), and g normalized Chinese loess grain size stack from North China (dark yellow line; Yang and Ding 2014). Refer to Fig. 1 for the location of the cores. Glacial stages are indicated with gray shading

conditions that the planktonic foraminifera inhabited, but the pattern closely follows the global benthic foraminifera LR04 stack (Lisiecki and Raymo 2005) and we interpret it as a global change in ice volume and temperature with minor local salinity effect. Previous studies interpreting $\varepsilon_{\mathrm{Nd}}$ as recording surface water composition concluded that Northern Hemisphere climatic forcing induced freshwater input and similar changes in oxygen isotopes and other salinity indicators (Burton and Vance 2000; Gourlan et al. 2010). Now that we know authigenic $\varepsilon_{\mathrm{Nd}}$ signatures are acquired in the bottom waters, more radiogenic $\varepsilon_{\mathrm{Nd}}$ during glacials likely reflects the stronger penetration of and the more radiogenic AABW ( $\varepsilon_{\mathrm{Nd}}-6.0$ to -6.8 in Antarctica; Howe et al. 2016) supplying the bottom water in the Indian Ocean. This in turn implies that the strength of the NADW was weaker during the glacial periods. In addition, according to Singh et al. (2012)'s model, the release of $\mathrm{Nd}$ from particulate phases supplied by the Ganges-Brahmaputra river system extends a high-Nd water mass with nonradiogenic values at $\sim 2500 \mathrm{~m}$ water depth toward the open ocean. This effect would have been greater in the interglacials.

The comparison of $\varepsilon_{\mathrm{Nd}}$ and $\delta^{18} \mathrm{O}$ records yields some interesting observations. First, $\varepsilon_{\mathrm{Nd}}$ values tend to be more radiogenic during glacials. The most radiogenic and hence the strongest AABW signal appears in the Last Glacial Maximum (26.5-19 ka BP), and the previous glacials are weaker/less radiogenic in the order of MIS 6 and MIS 8. Both NADW and AABW become more radiogenic during the glacial periods, but more so for the NADW (note the $\varepsilon_{\mathrm{Nd}}$ axes of Figs. 5d and e). In the case of the $S$. Atlantic, in which AABW is actively mixed with NADW, the major G-IG cycles are consistent (Fig. 5e). Thus, in the glacial period the NADW ( -10) mixes with the AABW ( -6.0 to -6.8$)$ and yields the radiogenic $\varepsilon_{\mathrm{Nd}}$ $(-6$ to -8$)$ in the S. Atlantic and Indian oceans (note the bar of Fig. 5c, e).

Second, during the interglacials the $\varepsilon_{\mathrm{Nd}}$ values are less radiogenic, representing weakened/less radiogenic AABW. Other records in the Indian and Pacific oceans also reported weakened $A A B W$ invasion during the interglacials (Spero and Lea 2002; Anderson et al. 2009; Yu et al. 2018). The $\varepsilon_{\mathrm{Nd}}$ values are progressively less radiogenic in the order MIS 5, 7 , and 9. The most non-radiogenic values $(-10.5$ to -10.8$)$ of MIS 9 can be compared to those of Himalayan Rivers ( -16 to -14 ) or the Eastern Indian Ocean Water ( 10 to -9 ; Piepgras and Wasserburg 1982; Goswami et al. 2012; Yu et al. 2018).

Third, there are intervals during the interglacials when a significant mismatch with the climatic record occurs. The $\varepsilon_{\mathrm{Nd}}$ transition during the MIS 6/5 deglaciation is more sluggish than for the MIS 2/1 transition and is flat with little fluctuation during MIS 5 while the $\delta^{18} \mathrm{O}$ record follows the sawtooth pattern toward the 5/4 glacial-interglacial boundary. For some reason, the invasion of AABW remained suppressed in the late MIS 5 even though the climate was cooling. In MIS 7, there is an $\varepsilon_{\mathrm{Nd}}$ radiogenic peak (Fig. 5a; $228-215 \mathrm{ka})$ in a positively linear correlation with $\delta^{18} \mathrm{O}$. During an interval of warmth, the water circulation switched back to glacial mode and the AABW was strengthened. 


\section{Conclusions}

Neodymium isotopes in authigenic carbonates reveal the strength of past thermohaline circulation. The core used in this study, HI1808-GPC04, supplements the ODP 758 record over the past $330 \mathrm{kyr}$. Comparing this data set with the neighboring area (SK 129), the overall G-IG changes in $\varepsilon_{\mathrm{Nd}}$ were similar. This is a robust conclusion based on three different recording media-foraminiferal coating for HI1808-GPC04, foraminiferal lattice and bulk sediment leach for ODP 758, and bulk sediment leach for SK129, The AABW signal was relatively strong during the glacial period, and the NADW signal was stronger during the interglacial period in the equatorial Indian Ocean. However, there are non-radiogenic intervals (MIS 6/5 transition and MIS 7) within periods of stronger AABW. Dissolution of Himalaya-derived sediments is likely to be the dominant regional effect in the Ninetyeast Ridge (cores HI1808-GPC04/ODP 758) with additional input from the Andaman Sea. Considering that the regional $\varepsilon_{\mathrm{Nd}}$ differences (HI1808-GPC04/ODP 758 vs. SK129) are mostly constrained to the glacial period, sediment delivery from the Irrawaddy-Salween river system through the Andaman Sea (rather than the general Himalayan input) may be responsible for the detailed differences between the two sites. The results are useful for understanding regional responses and changes in global circulation accompanying climate change.

Acknowledgements This research was funded by the Mid-Career Researcher Program of the National Research Foundation of Korea (No. 2017R1A2B4005349) to Y Huh and by the research programs of the Korea Institute of Ocean Science and Technology (PE99583, PE9965A) and the National Research Foundation of Korea (No. 2019R1A2C1007701) to B-K Khim. We would like to thank the students (Joonsoek Lim, Hyunwoo Lee, and Mirae Kim) who helped with the method development. The constructive comments from the editor and two anonymous reviewers are gratefully acknowledged.

Open Access This article is licensed under a Creative Commons Attribution 4.0 International License, which permits use, sharing, adaptation, distribution and reproduction in any medium or format, as long as you give appropriate credit to the original author(s) and the source, provide a link to the Creative Commons licence, and indicate if changes were made. The images or other third party material in this article are included in the article's Creative Commons licence, unless indicated otherwise in a credit line to the material. If material is not included in the article's Creative Commons licence and your intended use is not permitted by statutory regulation or exceeds the permitted use, you will need to obtain permission directly from the copyright holder. To view a copy of this licence, visit http://creativecommons.org/licenses/by/4.0/.

\section{References}

Abbott AN, Haley BA, McManus J (2015) Bottoms up: Sedimentary control of the deep North Pacific Ocean's $\varepsilon_{\mathrm{Nd}}$ signature. Geology 43(11):1035-1038. https://doi.org/10.1130/G37114.1
Achyuthan H, Nagasundaram M, Gourlan AT, Eastoe C, Ahmad SM, Padmakumari VM (2014) Mid-Holocene Indian summer monsoon variability off the Andaman Islands, Bay of Bengal. Quat Int 349:232-244. https://doi.org/10.1016/j.quaint.2014.07.041

Ali S, Hathorne EC, Frank M (2021) Persistent provenance of south asian monsoon-induced silicate weathering over the past 27 million years. Paleoceanogr Paleoclimatol 36:e2020PA003909. https://doi.org/10.1029/2020PA003909

Anderson R, Ali S, Bradtmiller L, Nielsen S, Fleisher M, Anderson B, Burckle L (2009) Wind-driven upwelling in the Southern Ocean and the deglacial rise in atmospheric $\mathrm{CO}_{2}$. Science 323(5920):1443-1448. https://doi.org/10.1126/science.1167441

Basak C, Pahnke K, Frank M, Lamy F, Gersonde R (2015) Neodymium isotopic characterization of Ross Sea Bottom Water and its advection through the southern South Pacific. Earth Planet Sci Lett 419:211-221. https://doi.org/10.1016/j.epsl.2015.03.011

Basak C, Fröllje H, Lamy F, Gersonde R, Benz V, Anderson RF, Molina-Kescher M, Pahnke K (2018) Breakup of last glacial deep stratification in the South Pacific. Science 359(6378):900-904. https://doi.org/10.1126/science.aao2473

Böhm E, Lippold J, Gutjahr M, Frank M, Blaser P, Antz B, Fohlmeister J, Frank N, Andersen M, Deininger M (2015) Strong and deep Atlantic meridional overturning circulation during the last glacial cycle. Nature 517(7532):73-76. https:// doi.org/10.1038/nature14059

Burton KW, Vance D (2000) Glacial-interglacial variations in the neodymium isotope composition of seawater in the Bay of Bengal recorded by planktonic foraminifera. Earth Planet Sci Lett 176(3-4):425-441. https://doi.org/10.1016/S0012-821X(00) 00011-X

Chen J, Farrell JW, Murray DW, Prell WL (1995) Timescale and paleoceanographic implications of a 3.6 my oxygen isotope record from the northeast Indian Ocean (Ocean Drilling Program site 758). Paleoceanography 10(1):21-47. https://doi.org/10.1029/ 94PA02290

Colin C, Turpin L, Bertaux J, Desprairies A, Kissel C (1999) Erosional history of the Himalayan and Burman ranges during the last two glacial-interglacial cycles. Earth Planet Sci Lett 171:647-660. https://doi.org/10.1016/S0012-821X(99)00184-3

Damodararao K, Singh SK, Rai VK, Ramaswamy V, Rao PS (2016) Lithology, monsoon and sea surface current control on provenance, dispersal and deposition of sediments over the Andaman continental shelf. Front Mar Sci 3:118. https://doi.org/10.3389/ fmars.2016.00118

Du J, Haley BA, Mix AC (2016) Neodymium isotopes in authigenic phases, bottom waters and detrital sediments in the Gulf of Alaska and their implications for paleo-circulation reconstruction. Geochim Cosmochim Acta 193:14-35. https://doi.org/10.1016/j.gca. 2016.08.005

Farrell JW, Janacek TR (1991) Late Neogene paleoceanography and paleoclimatology of the northeast Indian Ocean (Site 758). In: Weissel J, Jeffrey A, Peirce J, Taylor E (eds) Ocean drilling program scientific results, vol 121, pp 297-355

Giosan L, Naing T, Min Tun M, Clift PD, Filip F, Constantinescu S, Khonde N, Blusztajn J, Buylaert J-P, Stevens T (2018) On the Holocene evolution of the Ayeyawady megadelta. Earth Surf Dyn 6(2):451-466. https://doi.org/10.5194/esurf-6-451-2018

Goldstein SL, Hemming SR (2003) Long-lived isotopic tracers in oceanography, paleoceanography, and ice-sheet dynamics. Treat Geochem 6:625. https://doi.org/10.1016/B0-08-043751-6/ 06179-X

Goswami V, Singh SK, Bhushan R, Rai VK (2012) Temporal variations in ${ }^{87} \mathrm{Sr} /{ }^{86} \mathrm{Sr}$ and $\varepsilon_{\mathrm{Nd}}$ in sediments of the southeastern Arabian Sea: impact of monsoon and surface water circulation. Geochem Geophys Geosystem 13:Q01001. https://doi.org/10.1029/2011G C003802 
Gourlan AT, Meynadier L, Allègre CJ, Tapponnier P, Birck J-L, Joron J-L (2010) Northern Hemisphere climate control of the Bengali rivers discharge during the past $4 \mathrm{Ma}$. Quat Sci Rev 29:24842498. https://doi.org/10.1016/j.quascirev.2010.05.003

Heaton TJ, Köhler P, Butzin M, Bard E, Reimer RW, Austin WEN, Bronk Ramsey C, Grootes PM, Hughen KA, Kromer B, Reimer PJ, Adkins J, Burke A, Cook MS, Olsen J, Skinner LC (2020) Marine20-the marine radiocarbon age calibration curve (0-55,000 cal BP). Radiocarbon 62:779-820. https://doi.org/10. 1017/RDC.2020.68

Hillaire-Marcel C, De Vernal A, Bilodeau G, Weaver AJ (2001) Absence of deep-water formation in the Labrador Sea during the last interglacial period. Nature 410(6832):1073-1077. https://doi. org/10.1038/35074059

Howe JN, Piotrowski AM, Rennie VC (2016) Abyssal origin for the early Holocene pulse of unradiogenic neodymium isotopes in Atlantic seawater. Geology 44(10):831-834. https://doi.org/10. 1130/G38155.1

Hu R, Noble TL, Piotrowski AM, McCave IN, Bostock HC, Neil HL (2016) Neodymium isotopic evidence for linked changes in Southeast Atlantic and Southwest Pacific circulation over the last 200 kyr. Earth Planet Sci Lett 455:106-114. https://doi.org/10.1016/j. eps1.2016.09.027

Huang H, Gutjahr M, Eisenhauer A, Kuhn G (2020) No detectable Weddell Sea Antarctic Bottom Water export during the Last and Penultimate Glacial Maximum. Nat Commun 11(1):1-10. https:// doi.org/10.1038/s41467-020-14302-3

Jacobsen SB, Wasserburg GJ (1980) Sm-Nd isotopic evolution of chondrites. Earth Planet Sci Lett 50:139-155. https://doi.org/10.1016/ 0012-821X(80)90125-9

Jeandel C (1993) Concentration and isotopic composition of $\mathrm{Nd}$ in the South Atlantic Ocean. Earth Planet Sci Lett 117:581-591. https:// doi.org/10.1016/0012-821X(93)90104-H

Joussain R, Colin C, Liu Z, Meynadier L, Fournier L, Fauquembergue K, Zaragosi S, Schmidt F, Rojas V, Bassinot F (2016) Climatic control of sediment transport from the Himalayas to the proximal NE Bengal Fan during the last glacial-interglacial cycle. Quat Sci Rev 148:1-16. https://doi.org/10.1016/j.quascirev.2016.06.016

Lacan F, Jeandel C (2004) Neodymium isotopic composition and rare earth element concentrations in the deep and intermediate Nordic Seas: constraints on the Iceland Scotland Overflow Water signature. Geochem Geophys Geosystems 5(11):Q11006. https://doi. org/10.1029/2004GC000742

Lee J, Kim S, Lee JI, Cho HG, Phillips SC, Khim B-K (2020) Monsoon-influenced variation of clay mineral compositions and detrital Nd-Sr isotopes in the western Andaman Sea (IODP Site U1447) since the late Miocene. Palaeogeogr Palaeoclimatol Palaeoecol 538:109339. https://doi.org/10.1016/j.palaeo.2019. 109339

Liao J, Peng S, Wen X (2020) On the heat budget and water mass exchange in the Andaman Sea. Acta Oceanol Sin 39(7):32-41. https://doi.org/10.1007/s13131-019-1627-8

Lindhorst S, Betzler C, Kroon D (2019) Wind variability over the northern Indian Ocean during the past 4 million years-Insights from coarse aeolian dust (IODP exp. 359, site U1467, Maldives). Palaeogeogr Palaeoclimatol Palaeoecol 536:109371. https://doi. org/10.1016/j.palaeo.2019.109371

Lisiecki LE, Raymo ME (2005) A Pliocene-Pleistocene stack of 57 globally distributed benthic $\delta 180$ records. Paleoceanography 20:PA1003. https://doi.org/10.1029/2004PA001071

Mantyla AW, Reid JL (1995) On the origins of deep and bottom waters of the Indian Ocean. J Geophys Res Oceans 100(C2):2417-2439. https://doi.org/10.1029/94JC02564

McCoy-West AJ, Millet M-A, Burton KW (2017) The neodymium stable isotope composition of the silicate Earth and chondrites.
Earth Planet Sci Lett 480:121-132. https://doi.org/10.1016/j.epsl. 2017.10.004

Piepgras DJ, Jacobsen SB (1988) The isotopic composition of neodymium in the North Pacific. Geochim Cosmochim Acta 52:13731381. https://doi.org/10.1016/0016-7037(88)90208-6

Piepgras DJ, Wasserburg GJ (1982) Isotopic composition of neodymium in waters from the Drake Passage. Science 217(4556):207214. https://doi.org/10.1126/science.217.4556.207

Piepgras DJ, Wasserburg GJ (1987) Rare earth element transport in the western North Atlantic inferred from Nd isotopic observations. Geochim Cosmochim Acta 51:1257-1271. https://doi.org/ 10.1016/0016-7037(87)90217-1

Piotrowski AM, Galy A, Nicholl J, Roberts N, Wilson D, Clegg J, Yu J (2009) Indian Ocean circulation and productivity during the last glacial cycle. Earth Planet Sci Lett 285:179-189. https://doi.org/ 10.1016/j.epsl.2009.06.007

Piotrowski AM, Banakar VK, Scrivner AE, Elderfield H, Galy A, Dennis A (2012) Reconstructing deglacial North and South Atlantic deep water sourcing using foraminiferal $\mathrm{Nd}$ isotopes. Earth Planet Sci Lett 357:289-297. https://doi.org/10.1016/j.eps1.2012.09.036

Pufahl P, Maslin M, Anderson L, Brüchert V, Jansen F, Lin H, Perez M, Vidal L (1998) Lithostratigraphic summary for Leg 175: AngolaBenguela upwelling system. In: Wefer G, Berger WH, Richter C (eds) Ocean drilling program proceedings, initial reports 175, pp 533-542

Rahman M, Dustegir M, Karim R, Haque A, Nicholls RJ, Darby SE, Nakagawa H, Hossain M, Dunn FE, Akter M (2018) Recent sediment flux to the Ganges-Brahmaputra-Meghna delta system. Sci Total Environ 643:1054-1064. https://doi.org/10.1016/j.scitotenv. 2018.06.147

Roberts NL, Piotrowski AM, McManus JF, Keigwin LD (2010) Synchronous deglacial overturning and water mass source changes. Science 327(5961):75-78. https://doi.org/10.1126/science.11780 68

Roberts NL, Piotrowski AM, Elderfield H, Eglinton TI, Lomas MW (2012) Rare earth element association with foraminifera. Geochim Cosmochim Acta 94:57-71. https://doi.org/10.1016/j.gca. 2012.07.009

Robinson LF, van de Flierdt T (2009) Southern Ocean evidence for reduced export of North Atlantic Deep Water during Heinrich event 1. Geology 37(3):195-198. https://doi.org/10.1130/G2536 3A. 1

Robinson RAJ, Bird M, Oo NW, Hoey T, Aye MM, Higgitt D, Swe A, Tun T, Win SL (2007) The Irrawaddy river sediment flux to the Indian Ocean: the original nineteenth-century data revisited. J Geol 115:629-640. https://doi.org/10.1086/521607

Singh SP, Singh SK, Goswami V, Bhushan R, Rai VK (2012) Spatial distribution of dissolved neodymium and $\varepsilon_{\mathrm{Nd}}$ in the Bay of Bengal: Role of particulate matter and mixing of water masses. Geochim Cosmochim Acta 94:38-56. https://doi.org/10.1016/j.gca.2012. 07.017

Song Z, Wan S, Colin C, Yu Z, Révillon S, Jin H, Zhang J, Zhao D, Shi X, Li A (2021) Paleoenvironmental evolution of South Asia and its link to Himalayan uplift and climatic change since the late Eocene. Glob Planet Change 200:103459. https://doi.org/10. 1016/j.gloplacha.2021.103459

Southon J, Kashgarian M, Fontugne M, Metivier B, Yim W-S (2002) Marine reservoir corrections for the Indian Ocean and Southeast Asia. Radiocarbon 44:167-180. https://doi.org/10.1017/S0033 822200064778

Spero HJ, Lea DW (2002) The cause of carbon isotope minimum events on glacial terminations. Science 296(5567):522-525. https://doi. org/10.1126/science.1069401

Stichel T, Frank M, Rickli J, Haley BA (2012) The hafnium and neodymium isotope composition of seawater in the Atlantic sector of 
the Southern Ocean. Earth Planet Sci Lett 317:282-294. https:// doi.org/10.1016/j.epsl.2011.11.025

Stuiver M, Reimer PJ (1993) Extended 14C data base and revised CALIB $3.0{ }^{14} \mathrm{C}$ age calibration program. Radiocarbon 35:215230. https://doi.org/10.1017/S0033822200013904

Stuiver M, Reimer PJ, Reimer RW (2021) CALIB 8.2 [WWW program]. http://calib.org Accessed 27 Sep 2021

Suresh N, Bagati TN (1998) Calcium carbonate distribution in the Late Quaternary sediments of Bay of Bengal. Curr Sci India 74:977-984

Tachikawa K, Arsouze T, Bayon G, Bory A, Colin C, Dutay J-C, Frank N, Giraud X, Gourlan AT, Jeandel C (2014) Neodymium associated with foraminiferal carbonate as a recorder of seawater isotopic signatures. Quat Sci Rev 88:1-13. https://doi.org/10.1016/j. quascirev.2013.12.027

Tachikawa K, Piotrowski AM, Bayon G (2017) The large-scale evolution of neodymium isotopic composition in the global modern and Holocene ocean revealed from seawater and archive data. Chem Geol 457:131-148. https://doi.org/10.1016/j.chemgeo.2017.03. 018

Wasson RJ (2003) A sediment budget for the Ganga-Brahmaputra catchment. Curr Sci India 84:1041-1047

Wilson DJ, Piotrowski AM, Galy A, McCave IN (2012) A boundary exchange influence on deglacial neodymium isotope records from the deep western Indian Ocean. Earth Planet Sci Lett 341:35-47. https://doi.org/10.1016/j.eps1.2012.06.009
Wilson DJ, Piotrowski AM, Galy A, Banakar VK (2015) Interhemispheric controls on deep ocean circulation and carbon chemistry during the last two glacial cycles. Paleoceanography 30(6):621641. https://doi.org/10.1002/2014PA002707

Yang S, Ding Z (2014) A 249 kyr stack of eight loess grain size records from northern China documenting millennial-scale climate variability. Geochem Geophys Geosystems 15(3):798-814. https:// doi.org/10.1002/2013GC005113

Yu Z, Colin C, Ma R, Meynadier L, Wan S, Wu Q, Kallel N, Sepulcre S, Dapoigny A, Bassinot F (2018) Antarctic Intermediate Water penetration into the Northern Indian Ocean during the last deglaciation. Earth Planet Sci Lett 500:67-75. https://doi.org/10.1016/j. eps1.2018.08.006

Zahirovic S, Flament N, Dietmar Müller R, Seton M, Gurnis M (2016) Large fluctuations of shallow seas in low-lying Southeast Asia driven by mantle flow. Geochem Geophys Geosyst 17(9):35893607. https://doi.org/10.1002/2016GC006434

Zhisheng A, Clemens SC, Shen J, Qiang X, Jin Z, Sun Y, Prell WL, Luo J, Wang S, Xu H (2011) Glacial-interglacial Indian summer monsoon dynamics. Science 333(6043):719-723. https://doi.org/ $10.1126 /$ science. 1203752

Publisher's Note Springer Nature remains neutral with regard to jurisdictional claims in published maps and institutional affiliations. 